\title{
Biosimilars in the French and Polish System: Chosen Aspects of Reimbursement and Access
}

\author{
Olga Barszczewska \\ Master in Pharmaceutical Science, Medical University of Lodz, Lodz, Poland \\ e-mail: obarszczewska@gmail.com
}

\section{Ralph Chami}

Medical Doctor (MD), HEC Paris, Paris, France, e-mail: ralphchami@gmail.com

\section{Anna Piechota}

Ph.D., University of Lodz, Lodz, Poland, e-mail: anna.piechota@uni.lodz.pl

\section{Abstract}

The EU approved the first biosimilar drug in 2006. By 2017, the EU had authorized the highest number of biosimilars worldwide, acquiring considerable experience in their use and safety. In May 2019, the European Medicines Agency (EMA) search engine showed 54 authorized biosimilars. Biosimilars reduce public expenditure; however, the discussion about their potential disadvantages is still ongoing.

Each country adopts different regulations on the interchangeability, switching, and substitution of a reference medicine by its biosimilar, since the EMA does not regulate this issue. Additionally, each nation has a unique reimbursement system, which results in significant differences in patients' access to biosimilars. The importance of securing a higher availability of these cheaper versions of biological drugs is well-recognized.

The better the access to these biosimilars is, the lower the overall drug expenditure and need for rationing would be, and therefore the better treatment results.

The aim of this paper is to compare selected aspects of reimbursement and access to the EMA authorized biosimilar medicines in two countries - France and Poland. The stated drug policy goal of both countries is to significantly improve biosimilar implementation in the coming years.

The research is based on an analysis of four main sources: the EMA biosimilars database, the Polish reimbursement list published by the Polish Ministry of Health, and two French reimbursement databases published by the French Ministry of Health. An additional literature review was conducted. The expected results concentrate on differences in the number of reimbursed biosimilars, the average time between EMA authorization and country reimbursement decision date, and the availability 
of biosimilars registered outside of the centralized (EMA) procedure. These findings could identify areas of improvement and help with discussions on how to optimize the reach of biosimilars, as well as improve French-Polish collaboration on this matter.

Keywords: biosimilars, biosimilar medicines, healthcare system, reimbursement, access, EMA, Ministry of Health

JEL: H51, H75, I15, I18

\section{Introduction}

In April 2006, the European Medicines Agency (EMA) approved Human Growth Hormone Omnitrope (somatropin) by the pharmaceutical company Sandoz. The company convinced the EMA that their biosimilar product is a safe and effective alternative to the original biological product. This opened the doors to other biosimilars representing various therapeutic areas (EMA 2017). Since then, biological medicines have provided effective treatment options in a number of clinical specialties, including dermatology, gastroenterology, rheumatology, and oncology (O’Callaghan et al. 2019).

Innovative drugs are expanding in Europe, and their prices are sometimes reaching vertiginous levels. For instance, in May 2019, the pharmaceutical company Novartis announced the launch of a new drug, which would cost an estimated \$2.1million (Reuters 2019). While expenditures on drugs are rising rapidly, countries' budgets are not stretching accordingly. Price and volume are the two basic factors that pharmaceutical expenditures are based on. Consequently, governments have two tools at their disposal - regulations aimed at lowering drug prices or at reducing usage. At the same time, most advanced countries' populations are aging, while there are increasing pharmaceutical options for disease control (Gronde, Uyl-de Groot, Pieters 2017).

\section{Definition}

According to the EMA, a biosimilar can be defined as, 'a biological medicine highly similar to another biological medicine already approved in the EU (the so-called 'reference medicine')' (EMA 2017).

The purpose of these biosimilars is then to replicate the original biological medicine similarly to how a generic drug replicates a medicine produced by chemical methods (Gámez-Belmonte et al. 2018).

\section{Method of production and testing}

The difference between biosimilars and generics arises from their complex manufacturing process: the molecules are large (unlike small-molecule, chemically produced drugs), their structure is complex, and they come from a unique line of living cells (Si- 
moens et al. 2017; Gámez-Belmonte et al. 2018) developed as the patents for original biologicals expire. They are thus developed to replicate an original biological medicine just a generics are intended to replicate a chemically-synthesized medicine; however, there are important technical and regulatory differences between the two. Unlike chemical drugs, molecular identity cannot generally be established for any two biological drugs. Accordingly, their pharmacological properties cannot be assumed to be the same. This is due to the complexity of the production of biologicals and to the presence of minor natural variations in the molecular structure (collectively known as microheterogeneity. Thus, this process does not produce exact copies of the original drug but will include slight differences between the structure of the original and the copy molecules (EMA 2017). They end up being highly similar, but not identical to the originator biologic (Yelena Y Janjigian et al. 2018)

Testing the biosimilar starts with analytical studies that aim to show similarity in the structure of the molecule, meaning the amino acid sequence and the higher-order structure, as well as the functional similarity. Animal studies might follow in order to evaluate in vivo toxicity and bioactivity. Finally, a clinical trial program with headto-head comparison might be done in order to assess the pharmacokinetics, clinical safety and efficacy, as well as the immunogenicity of the biosimilar vs. the original biologic drug (Yelena Y Janjigian et al. 2018). If the original biologic has multiple indications, testing one indication and extrapolating to the rest should be possible, just as it is after major changes to a biologic's manufacturing process (EMA 2017).

\section{Cost}

It is estimated that the cost to develop a new biologic is close to $\$ 800$ million, whereas the cost to develop a biosimilar ranges from $\$ 75$ to $\$ 250$ million (Kiss, Fine, and Krawitz 2018). Biosimilars end up reducing payer costs by 20 to $30 \%$ when compared to the reference product. This cost reduction can vary widely between countries within the EU, as seen with the infliximab biosimilar costs in Norway (Trifirò, Marcianò, Ingrasciotta 2018).

More competition generally equals reduced healthcare costs for payers and patients, and this remains the case for treatment classes with the introduction of a biosimilar. This reduction in cost is not only due to the biosimilar's smaller price tag, but also to a decrease in the price for the original biologic. Price variation between different classes also seems to be largely dependent on the length of time a biosimilar has been on the market. The longer a treatment class has had a biosimilar, the cheaper it gets.

A notable issue with biosimilar cost assessments is a blind spot due to non-published discounting for countries. This has the effect of overstating the real cost of drugs. Prices are not the only factor impacting patient access - other factors include new indications or restrictions, changes in the economic conditions of the country, or changes in the prevalence of the disease (IQVIA 2018). 


\section{Volume}

The price reduction brought on by biosimilars is often accompanied by an increase in patient access, which can vary widely, and which is partly dependent on the initial volume of treatment in the country. Examples of these changes in patient access are a massive increase of $\sim 1900 \%$ in 'volume treatment days' in Bulgaria for GCS-F drugs, and increases of $\sim 400 \%$ for Austria and Poland in anti-TNF and EPO classes, respectively (IQVIA 2018).

\section{The question of interchangeability (difference vs. switching and substitution)}

Three terms are important in order to understand how biosimilars are used in practice: interchangeability, switching, and substitution. These three terms are often confused for one another and misunderstood.

Interchangeability refers to the option of exchanging two drugs while keeping the expected treatment effect. This could be exchanging an original biologic with a biosimilar, a biosimilar with its original biologic, or a biosimilar with another.

Switching is when the prescriber decides to exchange one drug for another with the same therapeutic intent.

Substitution is when the pharmacist dispenses one drug instead of another one (both being interchangeable) without consulting the prescriber (EMA 2017).

Richer countries are generally careful about allowing automatic substitution of biologics due to the question of immunogenicity, which will be discussed further below, whereas lower-income countries might encourage substitution in order to reduce healthcare costs (Trifirò, Marcianò, Ingrasciotta 2018).

There have been numerous debates about the interchangeability of biosimilars with reference products based on concerns of immunogenicity caused by switching between biological products. This immunogenicity could cause a reduction in efficacy and an increase in toxicity (Trifirò, Marcianò, Ingrasciotta 2018). It will vary depending on the characteristics of both the product (changes to the protein structure), the method of administration (intravenous versus subcutaneous, for example), as well as patient and illness factors (concomitant treatments, age, etc.).

However, harmful immunogenicity is unlikely after switching. A patient might be treated by a biologic drug for a long time, and switching or even manufacturing changes to the biologic are unlikely to trigger harmful reactions.

Long term data is lacking, though, and post-marketing monitoring by regulatory authorities is invaluable to know more about these rare immune reactions (EMA 2018). 


\section{Methodology}

All 54 biosimilars that are intended for human use and registered on the official EMA website (EMA 2019) through their centralized procedure are accounted for in this study. Biosimilars which were refused authorization by the EMA, or whose application was withdrawn by the company, were excluded. Biosimilars and biologics were included only once; any redundancies were excluded. Data were last checked on May $1^{\text {st }}$, 2019. The research was done by each of the authors independently. The final tally was 54 unique biosimilar drugs corresponding to 16 original biologics studied in this article.

In order to gather data about the reimbursement situation in both countries, official government websites were used. The main websites for the French part were two search engines:

- http://www.codage.ext.cnamts.fr/codif/bdm_it/index.php?p_site=AMELI (cnamts.fr, accessed: 1.05.2019) and

- http://base-donnees-publique.medicaments.gouv.fr/ (medicaments.gouv.fr, accessed: 1.05.2019).

The final check of those databases was done on May $1^{\text {st }}, 2019$.

In Poland, reimbursement lists have been published every two months since 2012 on the official website of the Polish Ministry of Health (MZ 2019). Data were collected by checking relevant lists. In order to collect data about biosimilars potentially reimbursed before 2012 (7 out of 54 registered drugs), older versions of the Polish Ministry of Health website were consulted. The last consulted list was the one valid from May $1^{\text {st }}, 2019$.

The reimbursement dates presented in this publication are the dates when the reimbursement decisions came into force, not the dates of the decisions themselves; If multiple dates were found (for example, for different indications), only the earliest date was kept. Also, in the case of multiple reimbursement levels, only the highest was included.

The average time between the EMA registration dates and the country reimbursement decision dates was measured in two ways. This was in order to reduce measuring errors induced by the less transparent and accessible pre-2012 Polish data. In 2012, the Polish "Act on Reimbursement of Medicines, Foodstuffs Intended for Particular Nutritional Purposes and Medical Devices" came into force. The first of two sets of calculations were done using all reimbursed biosimilars (35 out of 54). In the second set of calculations, the seven pre-2012 drugs were excluded.

Some other parameters, such as the lack of willingness of a pharmaceutical company to introduce a generic drug in a given market due to promotion costs or entry costs, market size, demand for the given drug, pricing strategy, or available quantities of biosimilars can play an important role in the usage and reimbursement of generics. However, access to this data is limited and often confidential, which is why the authors focused only on available and verified data presented in this article - the num- 
ber of reimbursed biosimilars, the average time between EMA authorization and the country reimbursement decision date, and the availability of biosimilars registered outside of the centralized (EMA) procedure.

\section{Results}

Based on the criteria listed above, 54 unique biosimilar medicinal products registered by the EMA through its centralized procedure and until May 2019 were accounted for. The biggest manufacturer by the sheer number of unique biosimilars was Sandoz $\mathrm{GmbH}$, with 11 biosimilars out of the 54 (20\%). The next manufacturers were: Celltrion Healthcare Hungary Kft (6 drugs), Pfizer Europe MA EEIG (5), Mylan S.A.S (4) and Samsung Bioepis NL B.V. (4).

Around 60\% were registered by the EMA between the beginning of 2017 until the end of 2018, so in only a 2-year period.

The 54 biosimilars represented 16 different original biologics. All the original drugs were reimbursed in France. In Poland, there were two exceptions. Forsteo (teriparatid) is not reimbursed, and Eprex (epoetin alfa) is no longer present on the reimbursement list.

Not all the biosimilars are reimbursed. The French healthcare system covers costs of 33 out of the 54 (61\%) registered biosimilars, whereas in Poland, 27 (50\%) of the 54 biosimilars are reimbursed (Graph 1).

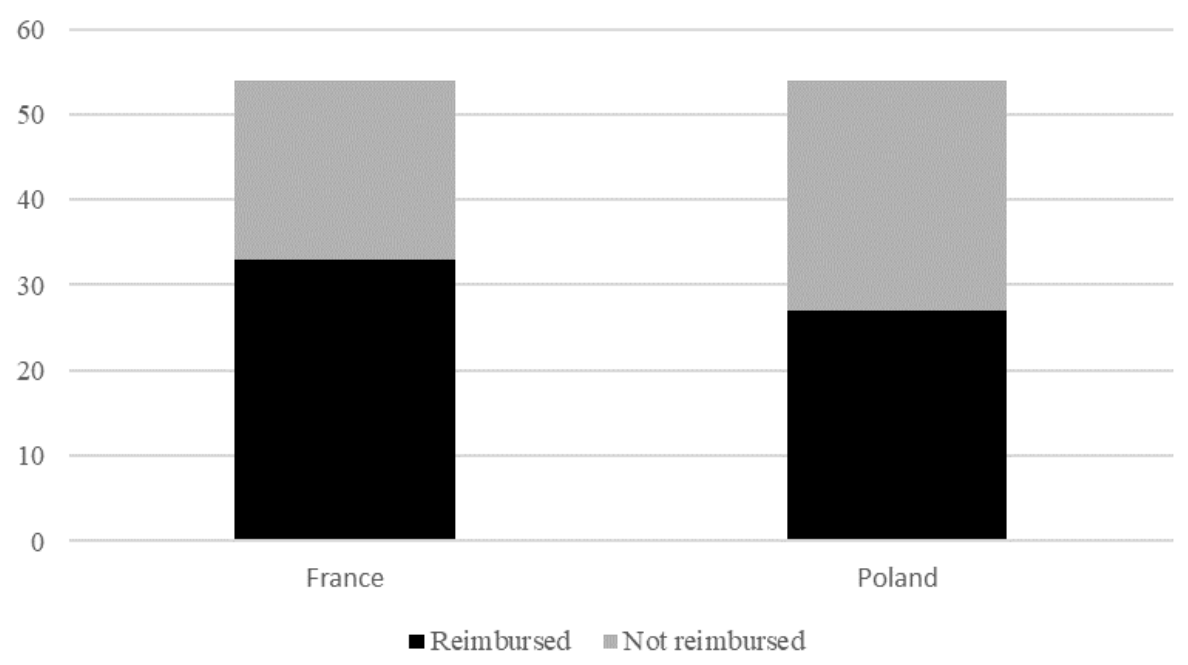

Graph 1. Number of reimbursed vs. non-reimbursed biosimilars in France and Poland Source: Polish and French health ministries' websites. 


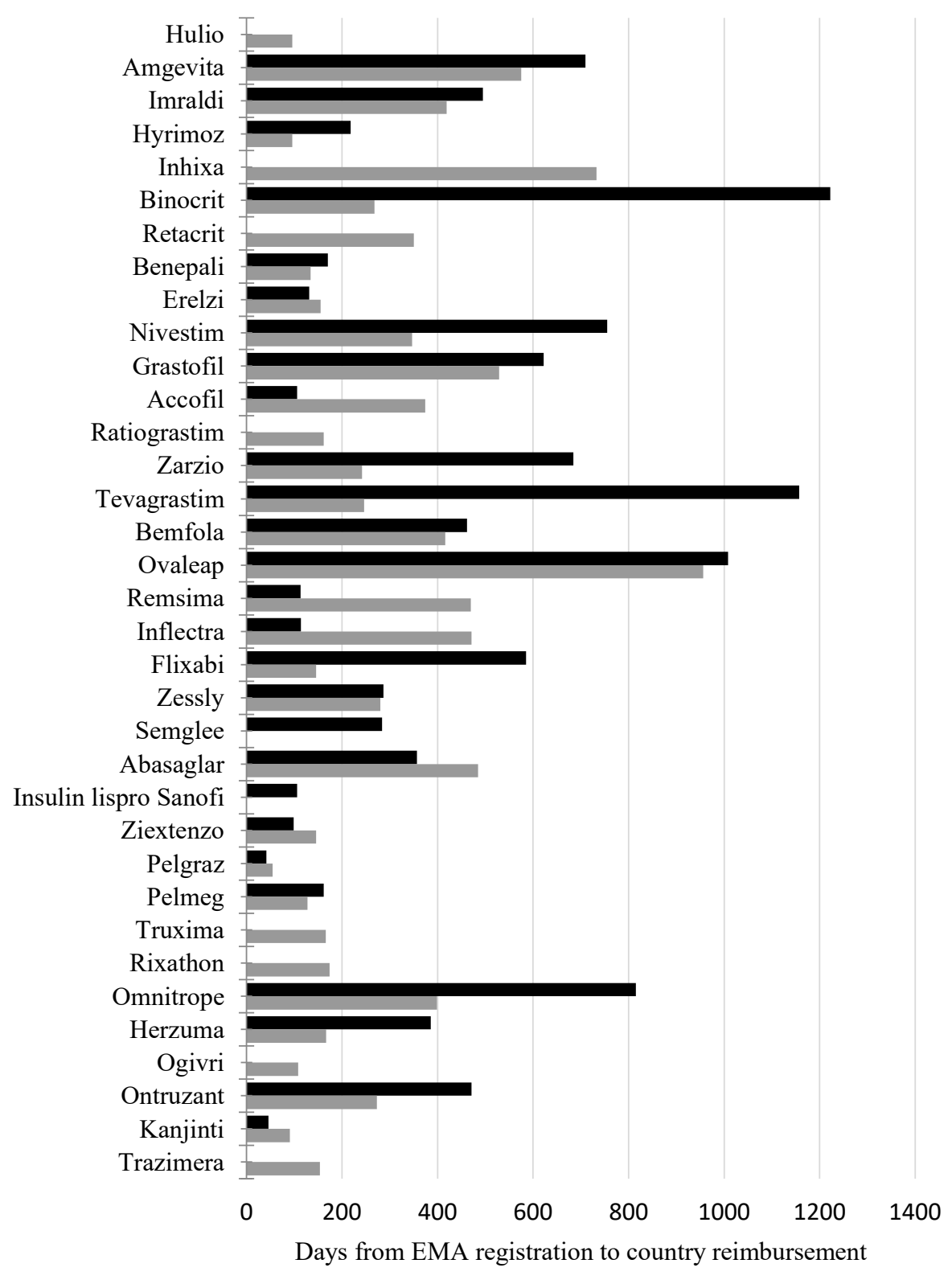

- Poland France

Graph 2. Number of days from EMA registration to reimbursement in Poland and France Source: websites of the Polish and French health ministries and the official EMA website (data last checked May $\left.1^{\text {st }}, 2019\right)$. 
Most of the time (in over $90 \%$ of cases), there were no other biosimilars reimbursed in either country and that were registered through a different procedure than the European centralized one.

In both countries, almost all the biosimilars are fully reimbursed, with no co-payment. In the Polish system, there were some exceptions where patients needed to pay a standard lump sum of 3.20 PLN (less than 1 EUR). As mentioned, the highest possible reimbursement percentage was collected in this research.

In 17 cases, France made reimbursement decisions faster than Poland did. The opposite was true for eight examples. Eight biosimilars were reimbursed in France but not in Poland, and 2 in Poland but not in France.

The average time between the EMA registration date and the reimbursement date in France was 297 days, which was 133 days shorter than in Poland, where the average time was 430 days. In the second set of calculations (without the seven pre-2012 drugs reimbursed in Poland), the results change to an average time of 300 days for France and 317 days for Poland (Graph 2). The trend is preserved in favor of France; however, the difference is only 17 days in this set of calculations.

\section{Discussion}

Biosimilar market penetration varies across European countries, going from 5\% for the share of biosimilar anti-tumor necrosis factor (anti-TNF) inhibitors in Ireland and Belgium to $90 \%$ in Denmark (O'Callaghan et al. 2019).

Of the 54 biosimilars representing 16 original biologics, only around 50 to $60 \%$ are reimbursed in France and Poland. Surprisingly, however, the percentage of drugs reimbursed is quite similar between the two countries despite the difference in the size of the two economies. Interestingly also for the patients, most biosimilars could be fully reimbursed.

The EMA registered 54 unique biosimilars representing 16 different original biologics. Meanwhile, France and Poland use $50-60 \%$ of them. Reimbursement uptake seems equal in both countries. The percentage of reimbursed drugs might further increase since $60 \%$ of the reimbursed drugs were registered only recently, between January 2017 and December 2018. From the patients' perspective, the most interesting outcome was that in both countries, almost all of the biosimilars were reimbursed at $100 \%$.

The main difference that was found between the two countries was the average time between the EMA registration date and the reimbursement date. In 17 cases, France made reimbursement decisions faster than Poland, and in only eight examples was the Polish decision faster. In France, the average time equaled 297 days (300 days in the set of calculations excluding drugs registered before 2012) and was shorter by 133 days (17 days in the second set of calculations) than the average Polish time, which equaled 430 days. The French reimbursement system seems to be slightly faster. 
A review of the press, literature, and legislation shows that both countries present similar and generally positive attitudes towards biosimilars. France and Poland are two of the few European countries that allow for the substitution of biologics by the pharmacist without the consent of the provider.

In Poland, biosimilar substitution can be applied in practice in most cases, despite some reservations by the national Polish pharmaceutical association, INFARMA (INFARMA 2019), regarding the treatment of biologics as if they were chemical drugs.

In France, on the other hand, some legislation has been introduced but not yet implemented. For now, this allows for substitution at treatment initiation, but not afterward, while informing the prescriber of the biosimilar name written on the prescription (data from 2017) (Rémuzat et al. 2017; O’Callaghan et al. 2019).

\section{Policy on biosimilars - France}

With Omnitrope (somatotropin) in 2006, France was the first country in Europe to authorize biosimilars. One of the goals of the 2018-2022 National Health Strategy established by the French Ministry of Health was the promotion of the correct use of medicines and the development of generics and biosimilars. Among the detailed actions listed in this plan, France aims for $80 \%$ biosimilar penetration by 2022 . This plan does not define what steps will be taken to achieve this goal, as the document only mentions developing digital tools to aid providers. The French 2014 budget pushed for pharmacy-level substitutions. The substitution policy was revamped in 2017. Another big step in 2017 was the creation of the biosimilar registry (Ministère des solidarités et de la santé 2018a, 2018b).

\section{Policy on biosimilars - Poland}

There is no separate definition of a biological medicine in the Polish legislation, which leads to interpretative ambiguities. Despite the clear EMA guidelines, biosimilars follow basically the same rules as generic medicines, particularly when it comes to substitution. Reducing costs is a major reason for this. This might have a negative impact on doctors' autonomy and patients' rights (DemosEUROPA 2015).

Two of the six strategic objectives presented in the Drug Policy of Poland for 2018-2022 are indirectly related to biosimilars. These include: (1) providing safe and effective medicines, available at the right place and at the right time, and (2) constantly improving the health of the population, by optimizing public expenditure, and ensuring the widest possible access to effective, safe and cost-effective therapies.

In order to achieve these strategic objectives, ten specific priorities have been set, of which one is "increasing the safety and stability of drug supplies by increasing the market share of drugs manufactured in Poland, including bioequivalent drugs" (Ministerstwo Zdrowia 2018). The topic of substitution was also widely discussed in the 
subsection concerning the reduction of patient co-payment. However, these parts do not specify whether it only refers to generics or also to biosimilars. This goal is to be achieved, among others, by conducting a coherent policy of substitution based on increasing the number of available therapeutic options; and strengthening educational activities (Ministerstwo Zdrowia 2018).

The Polish healthcare system aims to support innovation in the Polish medical industry. One of the ideas is the establishment of the Virtual Institute of Medical Biotechnology. The idea of this institute is to finance the best research teams in a selective and stable manner and then commercialize their research results (Ministerstwo Zdrowia 2018).

\section{Proposed solutions and examples}

Increasing market penetration means putting policies in place that encourage interchangeability with original biologics. Such policies involve tendering, incentivizing healthcare professionals, encouraging substitution, and improving awareness and perception of biosimilars among healthcare professionals.

Tendering: Multiple European countries have seen great success in reducing costs through their national tendering processes for biologicals. The Norwegian Drug Procurement Cooperation, for example, succeeded in reducing their costs for anti-TNF biologics by 39\% in 2014 and increasing it to 69\% in 2015 (O'Callaghan et al. 2019).

Incentivizing healthcare professionals and gainsharing: Prescription quotas for biologicals can be very successful for increasing biosimilar market penetration, with the example of epoetin biosimilars reaching 67\% of total sales in Germany in 2014-2015. In Sweden, the money saved in a hospital by switching pediatric patients to biosimilar somatropin was reinvested in its clinic. In France, a system of compensation on public health goals called ROSP includes the ratio of use of insulin glargine biosimilars for outpatients, but no other biologics. Extending the ROSP system to other biosimilars could increase market penetration as well.

Gainsharing: in France, the difference between the reimbursement tariff and the actual price paid is divided between hospitals and the social security system. Hospitals can avail these benefits only in particular circumstances (O'Callaghan et al. 2019).

On the Polish side, one idea which was particularly stressed during an experts' workshop in 2016 was the introduction of a definition for biological and biosimilar medicine on a statutory level. Another was the need for clarification on the conditions for substitution, recommending possible automatic substitution for patients initiating treatment but less so for those that have already started treatment, while insisting on the importance of consent by doctor and patient (EY Life Sciences 2018).

An active approach to education and information sharing was recommended, for example, by creating a post-registration evaluation system that focuses on the needs of doctors without adequate information. Other strategies were increased training of patients and physicians about medicines using EMA best practices and building 
a communication platform with information about biosimilars. Another suggestion is to create a registry of medical problems in the context of the use of biological medicines. There was a general consensus on the need to expand the information delivered by the Registration Office, including via social media (EY Life Sciences 2018).

\section{Conclusion}

Biosimilars do not just reduce costs for payers; they also have an effect on increased treatment access for patients. Currently, 50-60\% of biosimilars registered by the EMA are reimbursed in France and Poland. The research showed that the average time from EMA registration to reimbursement date is shorter in France. Both countries have expressed an interest in improving access to biosimilars by defining it as one of the goals in their national healthcare strategies. Further efforts in terms of discussion, education, and legislation in this field are required.

\section{References}

DemosEUROPA (2015), Leki biologiczne w polskim systemie ochrony zdrowia, DemosEUROPA - Centrum Strategii Europejskiej. Available at: https://www.infarma.pl /assets/files/innowacje/Leki_biologiczne_w_polskim_systemie_zdrowia_Raport _demosEUROPA.pdf (accessed: 2.07.2019)

European Medicines Agency and the European Commission (2017), Biosimilars in the EU. http://dx.doi.org/10.1201/9781315119878-15

EY Life Sciences (2018), Global biosimilar policy comparison, EY Life Sciences, pp. 50-59. Available at: https://www.eyadvisory.co.jp/services/documents/pdf/glo bal-biosimilar-policy-comparison-report_final.pdf (accessed: 3.07.2019)

Gámez-Belmonte, R. et al. (2018) Biosimilars: Concepts and controversies, "Pharmacological Research", Elsevier Ltd, Vol. 133, pp. 251-264. http://dx.doi.org/10.1016 /j.phrs.2018.01.024

Gronde, T. van der, Uyl-de Groot, C.A. and Pieters, T. (2017), Addressing the challenge of high-priced prescription drugs in the era of precision medicine: A systematic review of drug life cycles, therapeutic drug markets and regulatory frameworks, "PloS One", http://dx.doi.org/10.1371/journal.pone.0182613

IQVIA (2018), The Impact of Biosimilar Competition in Europe. Available at: http:// www.medicinesforeurope.com/wp-content/uploads/2017/05/IMS-Biosimilar-2017 _V9.pdf (accessed: 2.07.2019).

Janjigian, Y. Y., Bissig, M., Curigliano, G., Coppola, J., \& Latymer, M. (2018, October 1). Talking to patients about biosimilars. Future Oncology. Future Medicine Ltd. https:// doi.org/10.2217/fon-2018-0044

Kiss, S., Fine, H. F., Krawitz, J. (2018), Coming of Age: Biosimilars, "Ophthalmic Surgery, Lasers and Imaging Retina”, Vol. 49 (3), pp. 162-165. http://dx.doi.org/10.39 28/23258160-20180221-02 
Ministère des solidarités et de la santé (2018a), Stratégie nationale de santé. Available at: https://solidarites-sante.gouv.fr/systeme-de-sante-et-medico-social/strateg ie-nationale-de-sante/article/la-strategie-nationale-de-sante-2018-2022 (accessed: 10.06.2019)

Ministère des solidarités et de la santé (2018b), Summary of National Health Strategy 2018-2022. Available at: https://solidarites-sante.gouv.fr/IMG/pdf/dossier_sns_20 17_synthesev6-10p_anglaisv2.pdf (accessed: 9.07.2019)

Ministerstwo Zdrowia (2018), Polityka lekowa państwa 2018-2022, Polityka Zdrowotna. Available at: https:/www.politykazdrowotna.com/uploads/files/2018/07/16 /POLITYKA_LEKOWA_PANSTWA_2018-2022_12072018_v76.pdf (accessed: 3.06.2019)

O'Callaghan, J. et al. (2019), Regulation of biosimilar medicines and current perspectives on interchangeability and policy, "European Journal of Clinical Pharmacology. European Journal of Clinical Pharmacology", Vol. 75 (1). http://dx.doi.org/10 .1007/s00228-018-2542-1

Rémuzat, C., Kapuśniak, A., Caban, A.., Ionescu, Dan., Radière, G., Mendoza, C., Toumi, M. (2017), Supply-side and demand-side policies for biosimilars: an overview in 10 European member states, "Journal of Market Access \& Health Policy”, Vol. 5 (1), p. 1307315. http://dx.doi.org/10.1080/20016689.2017.1307315

Reuters (2019), \$2.1m Novartis gene therapy to become world's most expensive drug, "The Guardian”. Available at: https://www.theguardian.com/science/2019/may/25 $/ 21 \mathrm{~m}$-novartis-gene-therapy-to-become-worlds-most-expensive-drug (accessed: 8.07.2019)

Simoens, S., Jacobs, I., Popovian, R., Isakov, L., Shane, L.G. (2017), Assessing the Value of Biosimilars: A Review of the Role of Budget Impact Analysis, "PharmacoEconomics. Springer International Publishing”, Vol. 35 (10), pp. 1047-1062. http://dx .doi.org/10.1007/s40273-017-0529-x

Trifirò, G., Marcianò, I. and Ingrasciotta, Y. (2018), Interchangeability of biosimilar and biological reference product: Updated regulatory positions and pre-and post-marketing evidence, "Expert Opinion on Biological Therapy", Taylor \& Francis, Vol. 18 (3), pp. 309-315. http://dx.doi.org/10.1080/14712598.2018.1410134

\section{Internet sources}

cnamts.fr (2019), http://www.codage.ext.cnamts.fr/codif/bdm_it/index.php?p_site=A MELI (accessed: 1.05.2019).

EMA (2019), EMA - Europejska Agencja Leków (eng. European Medicines Agency), https://www.ema.europa.eu/en (accessed: 1.05.2019).

INFARMA (2019), https://www.infarma.pl/ (accessed: 11.08.2019).

medicaments.gouv.fr (2019), http://base-donnees-publique.medicaments.gouv.fr/ (accessed: 1.05 .2019$)$.

MZ (2019), MZ - Ministerstwo Zdrowia, EMA (2019), EMA - Europejska Agencja Leków (eng. European Medicines Agency), https://www.ema.europa.eu/en (accessed: 1.05.2019). 


\section{Streszczenie}

\section{Leki biopodobne we francuskim i polskim systemie: wybrane aspekty refundacji i dostępu}

Pierwszy lek biopodobny został zarejestrowany już w 2006 r. Od tego czasu, EMA zdobyła znaczne doświadczenie w ich wykorzystaniu oraz tworzeniu odpowiednich standardów bezpieczeństwa. W maju 2019 r., wyszukiwarka znajdująca się na oficjalnej stronie EMA, pokazała 54 unikatowe leki biopodobne zarejestrowane przez tę instytucję. Substancje biopodobne efektywnie zmniejszają wydatki publiczne, jednak dyskusja na temat ich potencjalnych wad wciąż trwa.

Ponieważ EMA nie reguluje tego zagadnienia, każdy kraj w Europie może przyjmować inne przepisy dotyczące zastępowalności, zamiany i zamienności leku referencyjnego przez odpowiadający mu biosymilar. Ponadto każdy kraj ma unikalny system refundacji, który powoduje znaczne różnice w dostępie pacjentów do leków biopodobnych. Potrzeba i korzyści związane ze zwiększeniem dostępności biosymilarów są dobrze rozpoznane przez decydentów i promowane przez wiele europejskich państw. Im lepszy dostęp do tych leków, tym niższe całkowite wydatki na leki i mniejsza potrzeba ich reglamentacji, a zatem lepsze wyniki leczenia.

Celem niniejszej publikacji jest porównanie wybranych aspektów refundacji i dostępu leków biopodobnych zatwierdzonych przez EMA w dwóch krajach - Francji i Polsce. W obu omawianych krajach, decydenci postawili sobie jako cel zintensyfikowanie wykorzystania biosymilarów w kolejnych latach. Francja została wybrana jako komparator do polskich standardów jako przykład bogatszego i bardziej rozwiniętego kraju europejskiego.

Przeprowadzone badania opierały się na analizie czterech głównych źródeł: bazy danych EMA, polskiej listy refundacyjnej opublikowanej przez polskie Ministerstwo Zdrowia oraz dwóch francuskich baz danych refundacyjnych opublikowanych przez francuskie Ministerstwo Zdrowia. Dodatkowo przeprowadzono przegląd literatury. Otrzymane wyniki koncentrują się na różnicach w liczbie refundowanych leków biopodobnych, średnim czasie między rejestracją EMA a datą rozpoczęcia refundacji oraz dostępności leków biopodobnych zarejestrowanych poza procedurą scentralizowaną (EMA). Wyniki mogą pomóc w identyfikacji potencjalnych obszarów do poprawy, a także wesprzeć dyskusję na temat optymalizacji dostępu do leków biopodobnych. Jest to również dodatkowy krok w stronę francusko-polskiej współpracy w zakresie biosymilarów.

Słowa kluczowe: biosymilary, leki biopodobne, system ochrony zdrowia, refundacja, dostęp, EMA, ministerstwo zdrowia 